Article

\title{
Precipitation Behavior and Quenching Sensitivity of a Spray Deposited Al-Zn-Mg-Cu-Zr Alloy
}

\author{
Xiaofei Sheng ${ }^{1,2} \mathbb{B}^{10}$, Qian Lei ${ }^{1,3, *}$, Zhu Xiao ${ }^{1}$ and Mingpu Wang ${ }^{1}$ \\ 1 School of Materials Science and Engineering, Central South University, Changsha 410083, China; \\ auden1@126.com (X.S.); xiaozhumse@163.com (Z.X.); wangmp@csu.edu.cn (M.W.) \\ 2 School of Materials Science and Engineering, Hubei University of Automotive Technology, \\ Shiyan 442002, China \\ 3 Department of Materials Science and Engineering, College of Engineering, University of Michigan, \\ Ann Arbor, MI 48109, USA \\ * Correspondence: qianlei@umich.edu; Tel.: +1-734-763-5282
}

Received: 17 August 2017; Accepted: 17 September 2017; Published: 19 September 2017

\begin{abstract}
Precipitation behavior and the quenching sensitivity of a spray deposited $\mathrm{Al}-\mathrm{Zn}-\mathrm{Mg}-\mathrm{Cu}-\mathrm{Zr}$ alloy during isothermal heat treatment have been studied systematically. Results demonstrate that both the hardness and the ultimate tensile strength of the studied alloy decreased with the isothermal treatment time at certain temperatures. More notably, the hardness decreases rapidly after the isothermal heat treatment. During isothermal heat treatment processing, precipitates readily nucleated in the medium-temperature zone $\left(250-400{ }^{\circ} \mathrm{C}\right)$, while the precipitation nucleation was scarce in the low-temperature zone $\left(<250{ }^{\circ} \mathrm{C}\right)$ and in the high-temperature zone $\left(>400{ }^{\circ} \mathrm{C}\right)$. Precipitates with sizes of less than ten nanometers would contribute a significant increase in yield strength, while the ones with a larger size than $300 \mathrm{~nm}$ would contribute little strengthening effect. Quenching sensitivity is high in the medium-temperature zone $\left(250-400{ }^{\circ} \mathrm{C}\right)$, and corresponding time-temperature-property (TTP) curves of the studied alloy have been established.
\end{abstract}

Keywords: spray deposition; microstructure; aluminum alloys; strength; precipitation

\section{Introduction}

In the past decades, 7xxx series (Al-Zn-Mg-Cu) aluminum alloys exhibited an outstanding performance and attracted much interest in many industry fields, especially in the automotive and the aviation field [1-3], because of their high strength, high ductility, and low density [4,5]. The high strength makes the products strong, and the high ductility allows the products to be easily forming during the machining process, and the low density saves the energy cost and reduces the carbon emission. Rolling, extrusion, drawing, and other conventional thermo-mechanical processing have limited capabilities to improve the strength of Al- $\mathrm{Zn}-\mathrm{Mg}-\mathrm{Cu}$ alloys [6-10]. To achieve a higher strength, some new technologies have been developed recently [11-14]. Severe plastic deformation (SPD) techniques, such as accumulative roll bonding [11], high-pressure torsion [12], equal channel angular pressing [13], and friction stir processing [14], were proven to be effective methods to refine the structure and enhance the strength. However, SPD techniques yield laboratory-scale samples, and they are still rare in industry [15]. Materials with fine grains usually exhibit a high strength (due to the Hall-Petch relation) [16-22]. The spray deposition technology has been developed rapidly [23,24]. Large-scale Al-Zn-Mg-Cu-Zr ingots with fine structure have been successfully fabricated by the spray deposition technology in our previous work $[25,26]$. The obtained ingots contain fine grains due to the rapid solidification and alloying [27-29]. Most investigations focus on the microstructure and properties of the spray-deposited $\mathrm{Al}-\mathrm{Zn}-\mathrm{Mg}-\mathrm{Cu}$ alloy in the lab scale $[26,30]$. Thermal heat treatment is an efficient method to enhance the properties. However, some critical process parameters should 
be reconsidered when the large ingots were turned to industrial products. For example, the solid solution-quenching treatment for precipitation hardening alloys is a very significant process, which would affect the followed aging process and the final properties [31]. In industry, ingots are about one ton in weight and a half cubic meter in volume, which are difficult to quench as fast as a sample with a lab-scale size. Decomposition will occur during the cooling down process. In addition, microstructure evolutions, precipitation behavior, properties variation, and quenching sensitivity of a spray deposited $\mathrm{Al}-\mathrm{Zn}-\mathrm{Mg}-\mathrm{Cu}$ alloy during isothermal heat treatment (IHT) have not been reported. In this work, large-scale Al-Zn-Mg-Cu-Zr ingots were synthesized by a spray deposition technology. Microstructure evolution and properties variation of the solid solution treated alloy during isothermal heat treatments were investigated systematically. Precipitation behavior, quenching sensitivity, and strengthening mechanisms have been discussed.

\section{Materials and Methods}

The studied alloy was synthesized with an SFZD-5000 type environmental chamber in Haoran company (Xinghua, China) [25,26]. The chemical compositions of the spray-deposited Al-Zn-Mg-Cu-Zr alloy are listed in Table 1 . Before the spray deposition process, blocks of $\mathrm{Al}, \mathrm{Zn}, \mathrm{Mg}, \mathrm{Cu}$, and $\mathrm{Al}-\mathrm{Zr}$ master alloy were melted, and then the molten melt was atomized by $\mathrm{N}_{2}$ gas. The distance of the atomizing deposition was $650 \mathrm{~mm}$, rod ingots were spray deposition formed with a size of $500 \mathrm{~mm}$ in diameter and $1800 \mathrm{~mm}$ in length. The as-deposited ingot was extruded at $420^{\circ} \mathrm{C}$ with an extrusion speed of $3 \mathrm{~mm} / \mathrm{s}$ and an extrusion ratio of $6.25: 1$ (500 $\mathrm{mm}$ to $200 \mathrm{~mm}$ in diameter). Experimental specimens were cut from the hot extruded rod, and they were solid solution treated at $470{ }^{\circ} \mathrm{C} / 1 \mathrm{~h}$ in the first furnace with a melted mixture of $50 \% \mathrm{NaNO}_{3}$ and $50 \% \mathrm{KNO}_{3}$, and then rapidly transferred into another muffle furnace with a certain temperature $\left(205-445^{\circ} \mathrm{C}\right)$ for isothermal heat treatment. Some of the isothermal heat treated specimens were aged at $120^{\circ} \mathrm{C}$ for $24 \mathrm{~h}$. Table 2 gives the detailed parameters of the samples after different heat treatments. The sample A solid solution treated at $470{ }^{\circ} \mathrm{C} / 1 \mathrm{~h}$ was used as a reference set.

Table 1. Chemical composition of studied Al-Zn-Mg-Cu-Zr alloy samples.

\begin{tabular}{ccccccccccc}
\hline Composition & $\mathbf{A l}$ & $\mathbf{Z n}$ & $\mathbf{M g}$ & $\mathbf{C u}$ & $\mathbf{Z r}$ & $\mathbf{F e}$ & $\mathbf{S i}$ & $\mathbf{T i}$ & $\mathbf{M n}$ & $\mathbf{C r}$ \\
\hline wt $\%$ & Bal. & 8.31 & 2.07 & 2.46 & 0.12 & 0.078 & 0.056 & 0.005 & 0.005 & 0.003 \\
at $\%$ & Bal. & 3.68 & 2.45 & 1.12 & 0.038 & 0.04 & 0.057 & 0.003 & 0.003 & 0.002 \\
\hline
\end{tabular}

Table 2. Heat treatment parameters of the samples with different methods.

\begin{tabular}{cccc}
\hline Sample No. & Solution Treatment & Isothermal Heat Treatment & Aging Treatment \\
\hline A & $470{ }^{\circ} \mathrm{C} / 1 \mathrm{~h}$ & $/$ & $/$ \\
$\mathrm{B}$ & $470^{\circ} \mathrm{C} / 1 \mathrm{~h}$ & $/$ & $120^{\circ} \mathrm{C} / 24 \mathrm{~h}$ \\
$\mathrm{C}$ & $470^{\circ} \mathrm{C} / 1 \mathrm{~h}$ & $205^{\circ} \mathrm{C} / 5 \mathrm{~s}(30 \mathrm{~min})$ & $/$ \\
$\mathrm{D}$ & $470^{\circ} \mathrm{C} / 1 \mathrm{~h}$ & $325^{\circ} \mathrm{C} / 5 \mathrm{~s}(40 \mathrm{~s}),(30 \mathrm{~min})$ & $/$ \\
$\mathrm{E}$ & $470^{\circ} \mathrm{C} / 1 \mathrm{~h}$ & $445^{\circ} \mathrm{C} / 5 \mathrm{~s},(30 \mathrm{~min})$ & $/$ \\
$\mathrm{F}$ & $470^{\circ} \mathrm{C} / 1 \mathrm{~h}$ & $205^{\circ} \mathrm{C} / 5 \mathrm{~s}(30 \mathrm{~min})$ & $120^{\circ} \mathrm{C} / 24 \mathrm{~h}$ \\
$\mathrm{G}$ & $470^{\circ} \mathrm{C} / 1 \mathrm{~h}$ & $325^{\circ} \mathrm{C} / 5 \mathrm{~s}(40 \mathrm{~s}),(30 \mathrm{~min})$ & $120^{\circ} \mathrm{C} / 24 \mathrm{~h}$ \\
$\mathrm{H}$ & $470^{\circ} \mathrm{C} / 1 \mathrm{~h}$ & $445^{\circ} \mathrm{C} / 5 \mathrm{~s}(30 \mathrm{~min})$ & $120^{\circ} \mathrm{C} / 24 \mathrm{~h}$ \\
\hline
\end{tabular}

Hardness measurements of heat treated specimens were conducted on a HV-5 Vickers hardness tester (Laizhou Huayin Testing Instrument Co., Ltd., Laizhou, China) to keep track of the hardness variation with the aging time. The load is $2 \mathrm{~kg}$, the dwell time is $15 \mathrm{~s}$, and each average hardness was taken from at least seven measurements. Flat-shoulder tensile test samples under the same condition were prepared with dimensions of a gage length of $25 \mathrm{~mm}$, and a width of $10 \mathrm{~mm}$. Tensile testing experiments were performed on an MTS 810 material testing machine (MTS Systems Corporation, Eden Prairie, MN, USA) at room temperature with a strain rate of $2 \mathrm{~mm} / \mathrm{min}$. Microstructure 
observations on the isothermal heat treatment specimens were operated on an FEI Tecnai G ${ }^{2}$ F20 transmission electron microscope (TEM) (FEI Company, Hillsboro, OR, USA) with an operation voltage of $200 \mathrm{kV}$. All TEM specimens were prepared by mechanical grinding, and then polished by a double-jet electropolishing device (MTP-1A) (Shanghai Jiao Da Electrical and Mechanical Technology Development Co., Ltd., Shanghai, China) at $-30{ }^{\circ} \mathrm{C}$ with a solution of $30 \%$ nitric acid $+70 \%$ methanol.

\section{Results}

\subsection{Microstructure Evolutions during Isothermal Heat Treatment and Aging}

For the as-spray deposited sample, there is no dendrite and segregation due to rapid solidification, and smaller grain size were detected in the spray deposited ingot, in comparison to that of the conventional casting ingots [32]. Bright-field (BF) images and selected area diffraction pattern (SADPs) of the studied alloy (sample A) having been solid solution treated at $470{ }^{\circ} \mathrm{C} / 1 \mathrm{~h}$ and quenched with water with a quenching rate of $200{ }^{\circ} \mathrm{C} / \mathrm{s}$ are shown in Figure 1. After solid solution treatment, metallic compounds precipitated during spray deposited process were re-dissolved into the matrix and a supersaturated solid solution (SSS) formed. The SADP in Figure 1a shows that a set of diffraction spots from Al were detected. The micrographs of the grain interior and grain boundary show that a SSS was formed after solid solution treatment (Figure 1b).

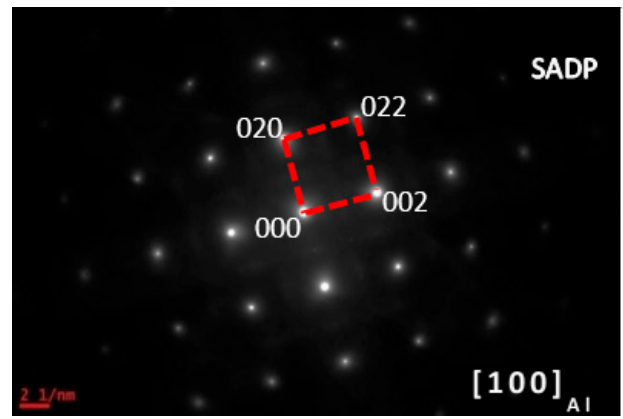

(a)

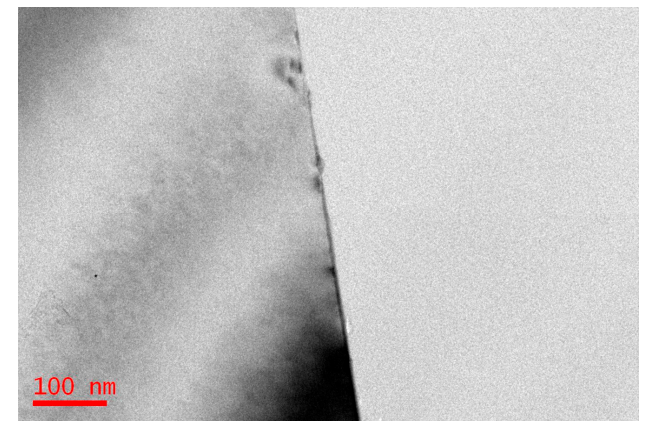

(b)

Figure 1. Microstructure and selected area diffraction patter (SADP) of the sample having been solution treated at $470{ }^{\circ} \mathrm{C}$ for $1 \mathrm{~h}$. (a) SADP of the sample, beam along to zone axis of [100] $]_{\mathrm{Al}}$; (b) bright-field image.

The BF image and corresponding SADPs of the solid solution treated alloy (sample B) are shown in Figure 2. After aging treatment at $120^{\circ} \mathrm{C}$ for $24 \mathrm{~h}$, some precipitates were formed with a size of $10 \mathrm{~nm}$ (Figure 2b). Some diffraction spots were from the precipitates, as seen in Figure 2a. According to the crystal geometry and crystal diffraction, indexing of the SADPs showed that the rod-like precipitates were $\eta^{\prime}-\mathrm{MgZn}_{2}$ phase, which has hexagonal lattice parameters of $\mathrm{a}=0.496 \mathrm{~nm}, \mathrm{c}=1.402 \mathrm{~nm}[33,34]$. A series of crystal orientation relationship between the matrix and $\eta^{\prime}$ phase could be calculated and proved: (001) $\eta^{\prime}$ I I (110)Al and [100] $\eta^{\prime}$ I I [001]Al [35]. The high strength of Al-Zn-Mg-Cu alloys are due to a significant number of $\eta^{\prime}$ phase precipitates [36]. Fine spherical $\mathrm{L}_{2}-\mathrm{Al}_{3} \mathrm{Zr}$ precipitates mixed with rod-like $\eta^{\prime}-\mathrm{MgZn}_{2}$ precipitates in Figure 1b, and SADP in Figure 1a, proved that the SSS was decomposed after aging at $120{ }^{\circ} \mathrm{C}$ for $24 \mathrm{~h}$.

Figure 3 shows the BF images and SADPs of the solid solution treated alloy having been isothermal heat treated at $205^{\circ} \mathrm{C}$ (quenching rate of $200^{\circ} \mathrm{C} / \mathrm{s}$ ) for different durations ( $5 \mathrm{~s}$ and $30 \mathrm{~min}$ ) (sample $\mathrm{C}$ ). After being isothermal heat treated at $205^{\circ} \mathrm{C}$ for $5 \mathrm{~s}$, more diffraction spots from precipitates were detected in SADP (Figure 3a). The bright-field image of the grain inside showed G. P. zone and $\mathrm{Al}_{3} \mathrm{Zr}$ were formed (Figure 3b). Increasing the IHT time to $30 \mathrm{~min}$, the SADP in Figure 3c presents some diffraction spots from $\eta^{\prime}$ precipitates, and the SSS was decomposed, and some precipitates with a size of $80 \mathrm{~nm}$ in length and $10 \mathrm{~nm}$ in diameter were detected (Figure 3d). Figure 4 shows BF images 
of the studied alloys having been isothermal heat treated at $325{ }^{\circ} \mathrm{C}$ for different durations $(5 \mathrm{~s}, 40 \mathrm{~s}$, and $30 \mathrm{~min}$ ) (sample D). After isothermal heat treated at $325^{\circ} \mathrm{C}$ for $5 \mathrm{~s}, \eta^{\prime}$ precipitates were detected with a size of $150 \mathrm{~nm}$ in length and $20 \mathrm{~nm}$ in diameter (Figure 4a). Increasing the IHT time to $40 \mathrm{~s}$, $\eta^{\prime}$ precipitates were coarsened to be a size of $250 \mathrm{~nm}$ in length and $100 \mathrm{~nm}$ in diameter (Figure $4 \mathrm{~b}$ ). Further increasing the IHT time to $30 \mathrm{~min}, \eta^{\prime}$ precipitates inside grain coarsened with a size of $400 \mathrm{~nm}$ in length and $80 \mathrm{~nm}$ in diameter (Figure 4c). BF images and SADPs of the studied alloy having been isothermal heat treated at $445^{\circ} \mathrm{C}$ for different durations (5 s and $30 \mathrm{~min}$ ) (sample E) are shown in Figure 5. After isothermal heat treatment at $445^{\circ} \mathrm{C}$ for $5 \mathrm{~s}$ even $30 \mathrm{~min}$, there is few diffraction spots from precipitates were detected in the SADP (Figure 5a), and there are few precipitates (Figure 5b,c).

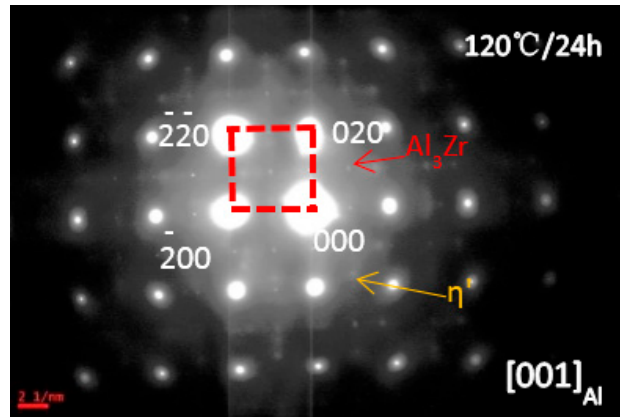

(a)

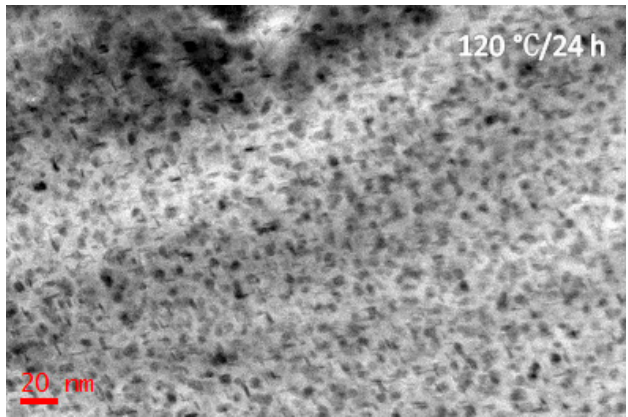

(b)

Figure 2. Bright-field (BF) images of the studied alloy having been solid solution treated at $470{ }^{\circ} \mathrm{C}$ for $1 \mathrm{~h}$ and then directly aged at $120^{\circ} \mathrm{C}$ for $24 \mathrm{~h}$. (a) SADP, the beam along zone axis of [100] $]_{\mathrm{Al}}$; (b) bright-field image.

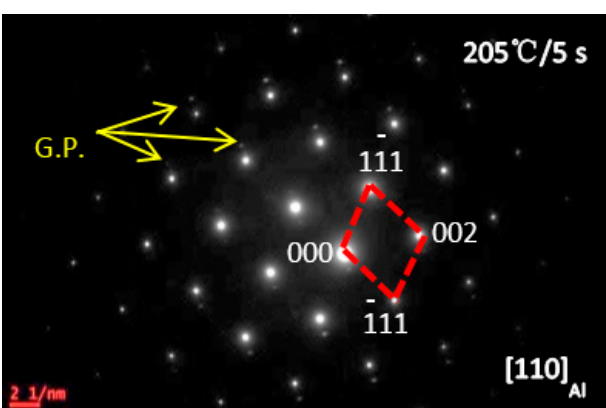

(a)

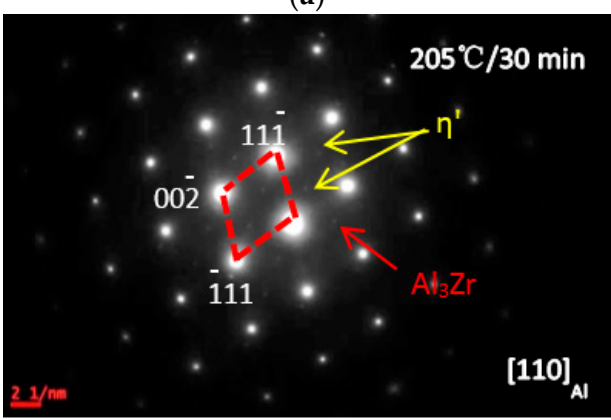

(c)

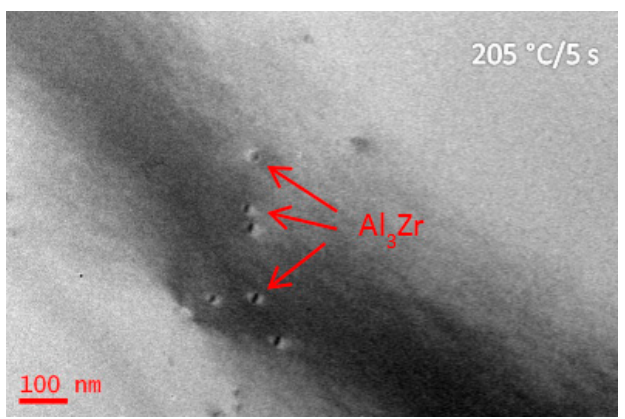

(b)

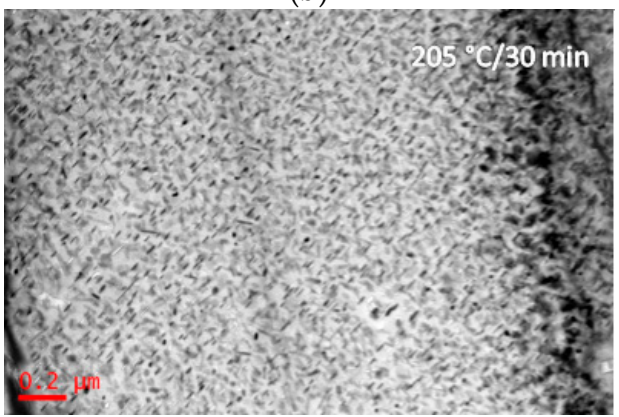

(d)

Figure 3. SADPs and BF images of the specimens having been isothermal heat treated at $205^{\circ} \mathrm{C}$ for different durations (5 $\mathrm{s}$ and $30 \mathrm{~min}$ ). (a) SADP of (b), beam along [110] $]_{\mathrm{Al}}$; (b) the IHT time is $5 \mathrm{~s}$; (c) SADP of $(\mathrm{d})$, beam along $[110]_{\mathrm{Al}}$; and(d) the isothermal heat treatment (IHT) time is $30 \mathrm{~min}$. 


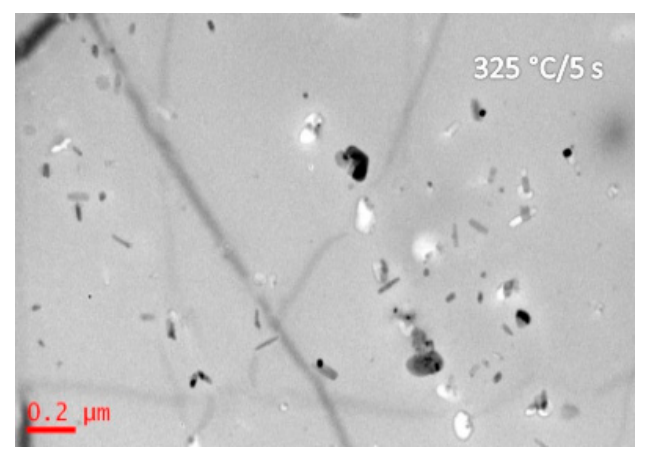

(a)

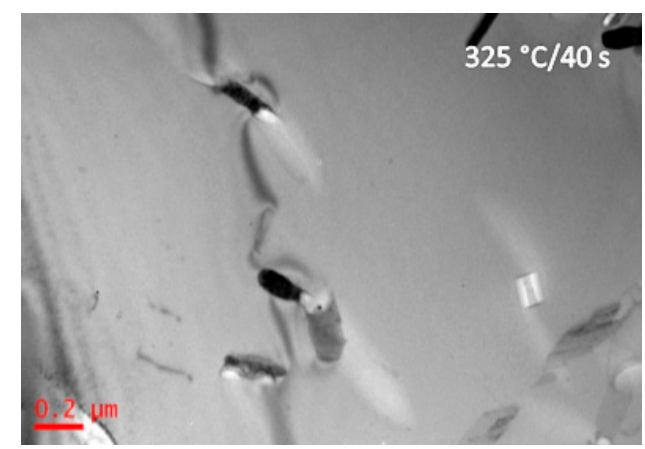

(b)

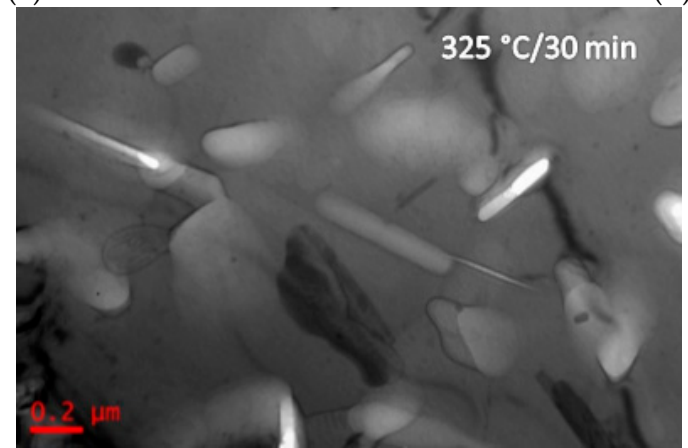

(c)

Figure 4. $\mathrm{BF}$ images of the studied alloy having been isothermal heat treated at $325{ }^{\circ} \mathrm{C}$ for different durations. The IHT durations are: (a) $5 \mathrm{~s}$; (b) $40 \mathrm{~s}$; and, (c) $30 \mathrm{~min}$.

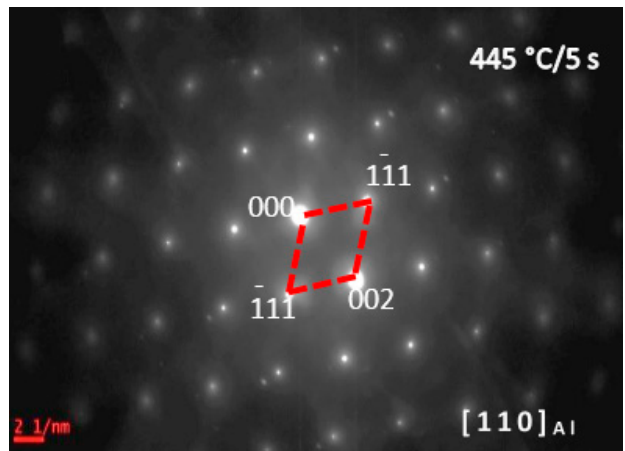

(a)

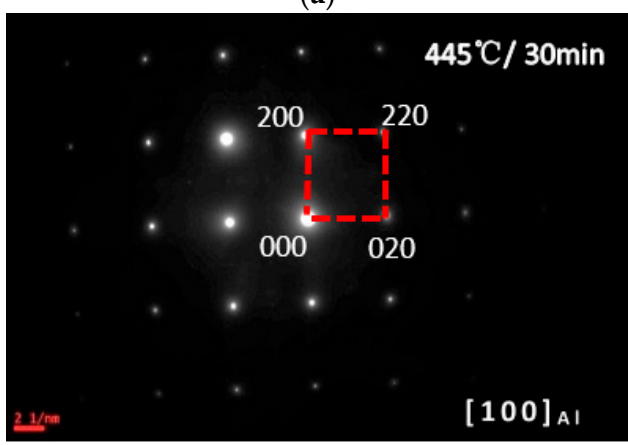

(c)

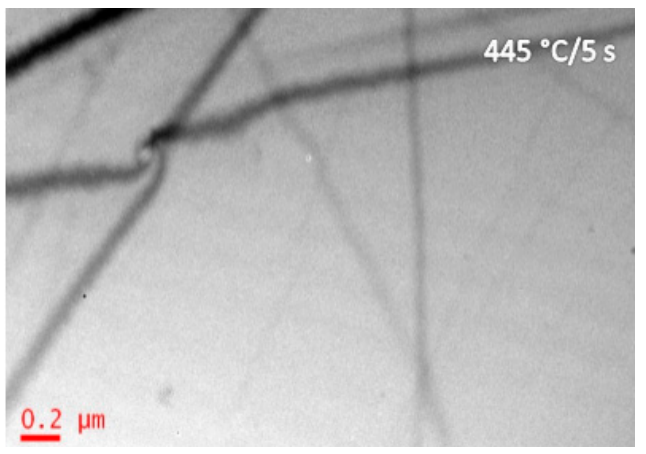

(b)

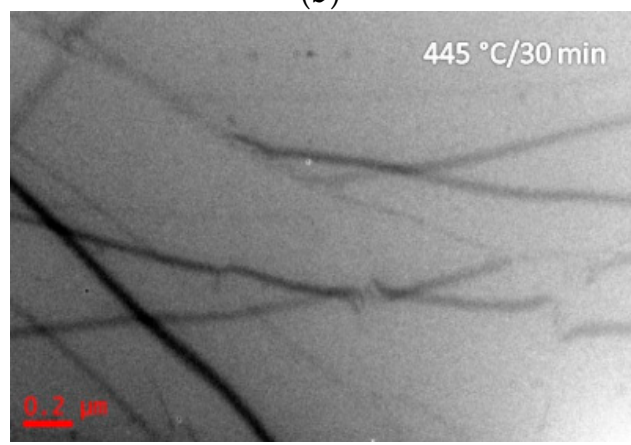

(d)

Figure 5. SADPs and BF images of the studied alloy having been isothermal heat treated at $445{ }^{\circ} \mathrm{C}$ for $5 \mathrm{~s}$ and $30 \mathrm{~min}$. (a) SADP from the area in (b); (b) the isothermal heat treatment time is $5 \mathrm{~s}$; (c) SADP from the area in (d); and (d) BF image, the isothermal heat treatment time is $30 \mathrm{~min}$. 
Figure 6 shows BF images and SADPs of the solution treated alloy having been isothermally heat treated at $205^{\circ} \mathrm{C}$ for different durations ( $5 \mathrm{~s}$ and $30 \mathrm{~min}$ ), and then aged at $120^{\circ} \mathrm{C}$ for $24 \mathrm{~h}$ (sample F). After the sample was treated at $205^{\circ} \mathrm{C}$ for $5 \mathrm{~s}$ and aged at $120^{\circ} \mathrm{C}$ for $24 \mathrm{~h}$, some diffraction spots from $\eta^{\prime}$ and $\mathrm{Al}_{3} \mathrm{Zr}$ precipitates were detected in the SADP (Figure 6a), and the bright-field images of grain inside and grain boundary also shows many $\eta^{\prime}$ precipitates, whose size was $20-40 \mathrm{~nm}$ (Figure $6 \mathrm{~b}$ ). Increasing the IHT time to $30 \mathrm{~min}$, the SADP in Figure $6 \mathrm{c}$ presented many diffraction spots from precipitates, and many coarse $\eta^{\prime}$ precipitates with a size of $100 \mathrm{~nm}$ in length and $10 \mathrm{~nm}$ in diameter were detected (Figure 6d).

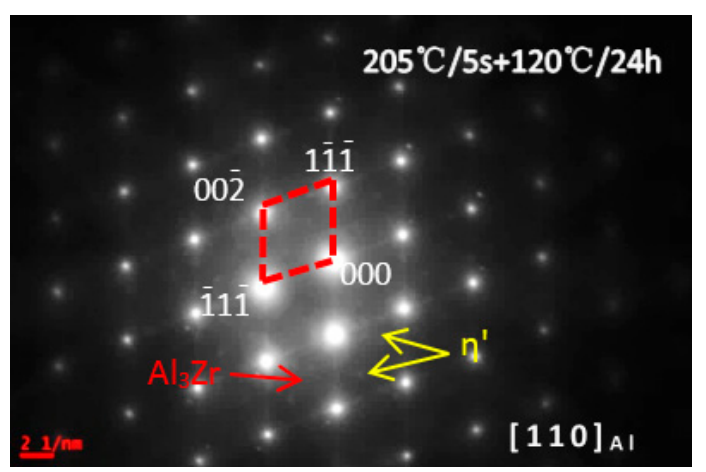

(a)

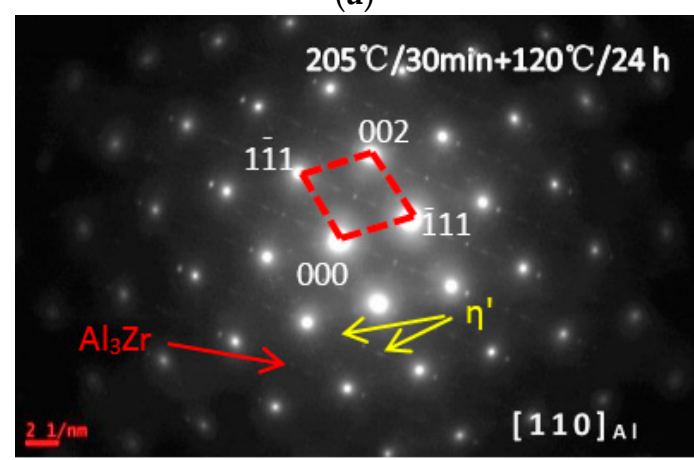

(c)

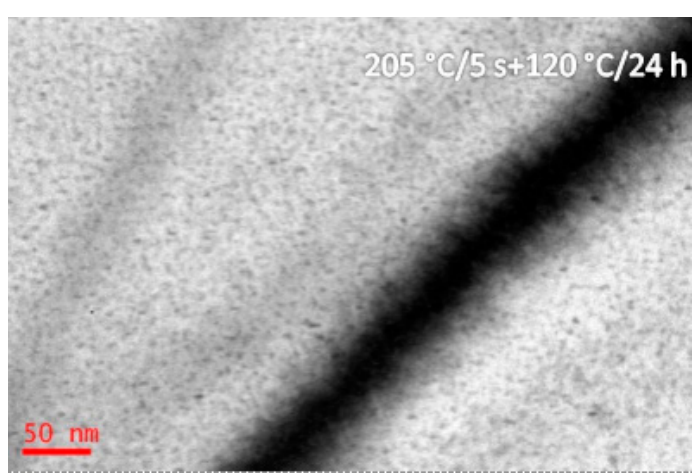

(b)

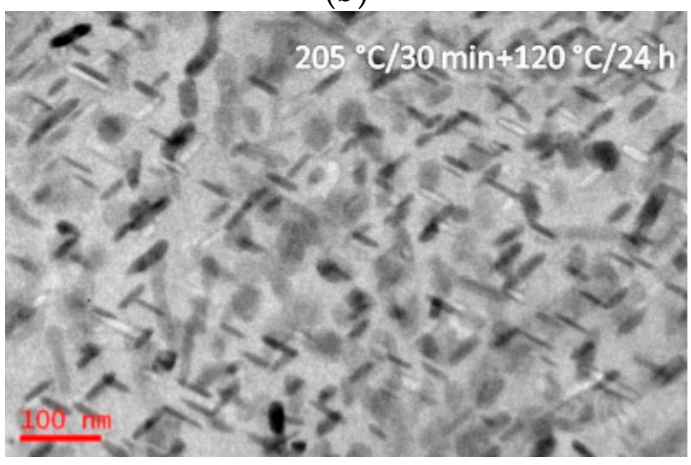

(d)

Figure 6. SADPs and BF images of the studied alloy having been isothermal heat treated at $205^{\circ} \mathrm{C}$ for different durations ( $5 \mathrm{~s}$ and $30 \mathrm{~min}$ ), and then aged at $120^{\circ} \mathrm{C}$ for $24 \mathrm{~h}$. (a) SADP from the area in (b); (b) the isothermal heat treatment is $5 \mathrm{~s}$; (c) SADP from the area in (d); and (d) isothermal heat treatment is $30 \mathrm{~min}$.

Bright-field TEM images and SADPs of the solution treated alloy having been annealed at $325{ }^{\circ} \mathrm{C}$ for different durations ( $5 \mathrm{~s}, 40 \mathrm{~s}$, and $30 \mathrm{~min}$ ), and then aged at $120^{\circ} \mathrm{C}$ for $24 \mathrm{~h}$ (Sample G) are shown in Figure 7. After isothermal heat treated at $325^{\circ} \mathrm{C}$ for $5 \mathrm{~s}$ and aging at $120^{\circ} \mathrm{C}$ for $24 \mathrm{~h}, \eta^{\prime}$ precipitates were formed with a size of 10-20 nm (Figure 7a). Increasing the IHT time to $40 \mathrm{~s}$, coarse $\eta^{\prime}$ precipitates were formed with a length of $300 \mathrm{~nm}$ and a diameter of $30 \mathrm{~nm}$ (Figure $7 \mathrm{~b}$ ). Increasing the IHT time to $30 \mathrm{~min}$, $\eta^{\prime}$ precipitates with a size of $300 \mathrm{~nm}$ in length and $100 \mathrm{~nm}$ in diameter (Figure 7c). Figure 8 shows $\mathrm{BF}$ images of the solution treated alloy having been isothermal heat treated at $445^{\circ} \mathrm{C}$ for different durations ( $5 \mathrm{~s}$ and $30 \mathrm{~min}$ ), and then aged at $120^{\circ} \mathrm{C}$ for $24 \mathrm{~h}$ (sample H). After isothermal heat treated at $445{ }^{\circ} \mathrm{C}$ for $5 \mathrm{~s}$ and aged at $120^{\circ} \mathrm{C}$ for $24 \mathrm{~h}$, some $\eta^{\prime}$ precipitates were detected with a size of $10-20 \mathrm{~nm}$ (Figure 8a), and they maintained same size even if isothermal heat treated for $30 \mathrm{~min}$ (Figure 8b). $\mathrm{Al}_{3} \mathrm{Zr}$ precipitates were also detected in these specimens (Figures 7 and 8 ). 


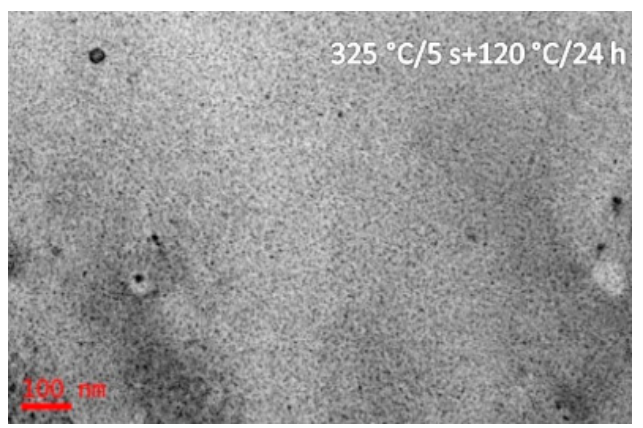

(a)

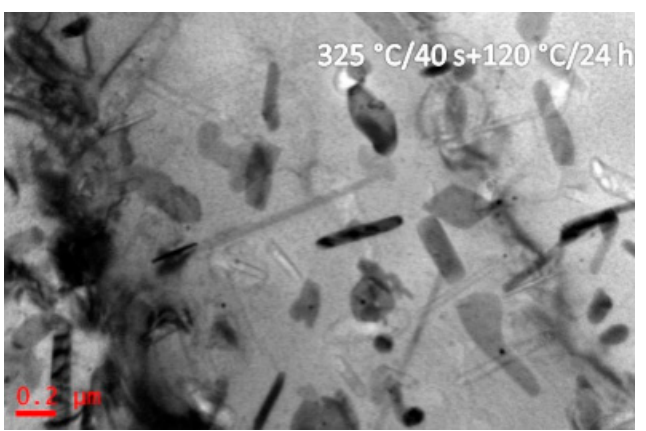

(b)

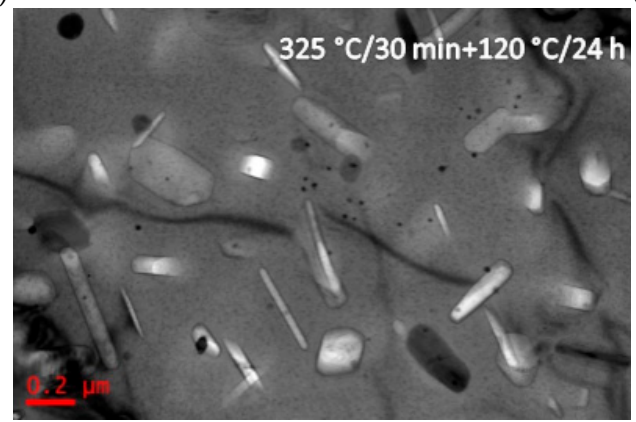

(c)

Figure 7. BF images of the studied alloy having been isothermal heat treated at $325{ }^{\circ} \mathrm{C}$ for different durations ( $5 \mathrm{~s}, 40 \mathrm{~s}$, and $30 \mathrm{~min}$ ), and then aged at $120{ }^{\circ} \mathrm{C}$ for $24 \mathrm{~h}$. The isothermal heat treatment durations are: (a) $5 \mathrm{~s}$; (b) $40 \mathrm{~s}$; and, (c) $30 \mathrm{~min}$.

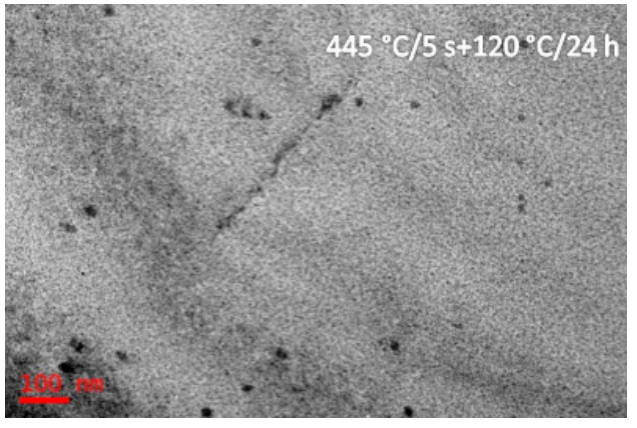

(a)

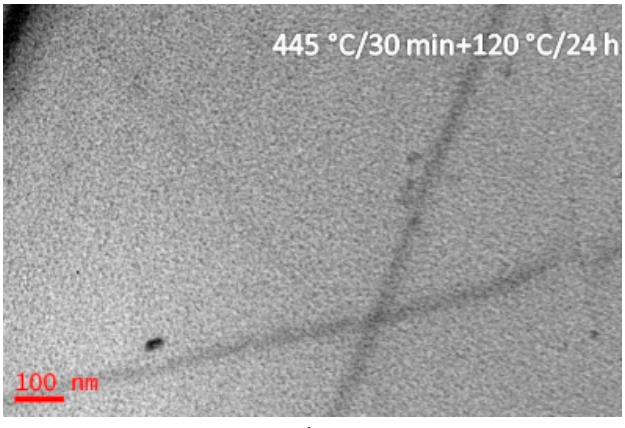

(b)

Figure 8. BF images of the studied alloy having been isothermal heat treated at $445^{\circ} \mathrm{C}$ for different durations ( $5 \mathrm{~s}$ and $30 \mathrm{~min}$ ), and then aged at $120^{\circ} \mathrm{C}$ for $24 \mathrm{~h}$. The isothermal heat treatment durations are: (a) $5 \mathrm{~s}$; (b) $30 \mathrm{~min}$.

\subsection{Hardness Variation}

The effect of IHT on the mechanical properties of the alloy was investigated through hardness measurements. Figure 9 shows the hardness variation versus the isothermally heat treated time on studied alloy samples having been solution treated at $470{ }^{\circ} \mathrm{C}$ for $1 \mathrm{~h}$ and quenched (cooling rate of $200{ }^{\circ} \mathrm{C} / \mathrm{s}$ ), isothermal heat treated at different temperatures for various durations, and then aged at $120^{\circ} \mathrm{C}$ for $24 \mathrm{~h}$. With increasing the IHT time, the hardness decreased successively in all IHT temperatures. Especially when the samples were isothermal heat treated at $295^{\circ} \mathrm{C}$ (or $325^{\circ} \mathrm{C}$ ) for $3 \mathrm{~min}$, the hardness values were rapidly decreased from $210 \mathrm{HV}$ to $110 \mathrm{HV}$ for $295^{\circ} \mathrm{C}$, and from $210 \mathrm{HV}$ to $120 \mathrm{HV}$ for $325^{\circ} \mathrm{C}$. However, when samples were isothermal heat treated at $205^{\circ} \mathrm{C}$ (sample F), the hardness decreased slightly. The hardness decreased from $210 \mathrm{HV}$ to $198 \mathrm{HV}$ when the sample was isothermal heat treated at $205^{\circ} \mathrm{C}$ for $3 \mathrm{~min}$. When a specimen was solution treated at $470{ }^{\circ} \mathrm{C}$ for 
$1 \mathrm{~h}$ and then immediately aged at $120^{\circ} \mathrm{C}$ for $24 \mathrm{~h}$ (sample A), the hardness was as high as $210 \mathrm{HV}$. The hardness of specimens decreased slightly from $210 \mathrm{HV}$ to $202 \mathrm{HV}$ when the SSS specimens were transferred into a furnace at the temperature of $445^{\circ} \mathrm{C}$ and kept for $3 \mathrm{~min}$, followed by aging at $120^{\circ} \mathrm{C}$ for $24 \mathrm{~h}$ (sample H). As samples were transferred into the IHT furnace, kept warm in the furnace for $30 \mathrm{~min}$, and then followed by aged at $120^{\circ} \mathrm{C}$ for $24 \mathrm{~h}$, the hardness of specimens was less than $160 \mathrm{HV}$. Further increasing the IHT time, hardness decreased successively.

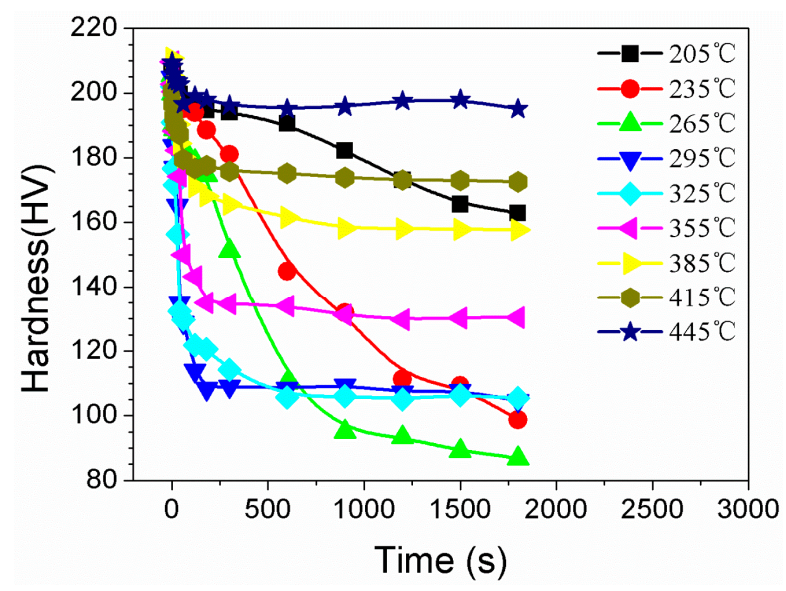

Figure 9. Hardness variation via the isothermal treated time on the studied samples having been solution treated at $470{ }^{\circ} \mathrm{C}$ for $1 \mathrm{~h}$, isothermal heat treated for various durations, and then aged at $120^{\circ} \mathrm{C}$ for $24 \mathrm{~h}$.

\subsection{Stress-Strain Curves}

Figure 10 shows the tensile stress-strain curves of the tensile samples. For the solid solution treated sample directly aged at $120^{\circ} \mathrm{C}$ for $24 \mathrm{~h}$ (sample A), the ultimate tensile strength was $719.8 \mathrm{MPa}$. While for samples having been isothermal heat treated at $205^{\circ} \mathrm{C}, 325^{\circ} \mathrm{C}, 445^{\circ} \mathrm{C}$, then aged at $120^{\circ} \mathrm{C}$ for $24 \mathrm{~h}$, the ultimate tensile strengths were $620.2 \mathrm{MPa}$ (for $205^{\circ} \mathrm{C}$, sample $\mathrm{F} / 5 \mathrm{~s}$ ), $606.4 \mathrm{MPa}$ (for $325^{\circ} \mathrm{C}$, sample $\mathrm{G} / 5 \mathrm{~s}$ ), and $647.5 \mathrm{MPa}$ (for $445^{\circ} \mathrm{C}$, sample $\mathrm{H} / 5 \mathrm{~s}$ ), respectively. While for samples having been isothermal heat treated at $205^{\circ} \mathrm{C}, 325^{\circ} \mathrm{C}, 445^{\circ} \mathrm{C}$ for $30 \mathrm{~min}$, and then aged at $120^{\circ} \mathrm{C}$ for $24 \mathrm{~h}$, the ultimate tensile strength values were $524.5 \mathrm{MPa}$ (for $205^{\circ} \mathrm{C}$, sample $\mathrm{G} / 30 \mathrm{~min}$ ), $300.1 \mathrm{MPa}$ (for $325^{\circ} \mathrm{C}$, sample $\mathrm{G} / 30 \mathrm{~min}$ ), and $647.5 \mathrm{MPa}$ (for $445{ }^{\circ} \mathrm{C}$, sample $\mathrm{G} / 30 \mathrm{~min}$ ). Table 3 shows the detailed mechanical properties of the specimens with different heat treatments (see Table 2).

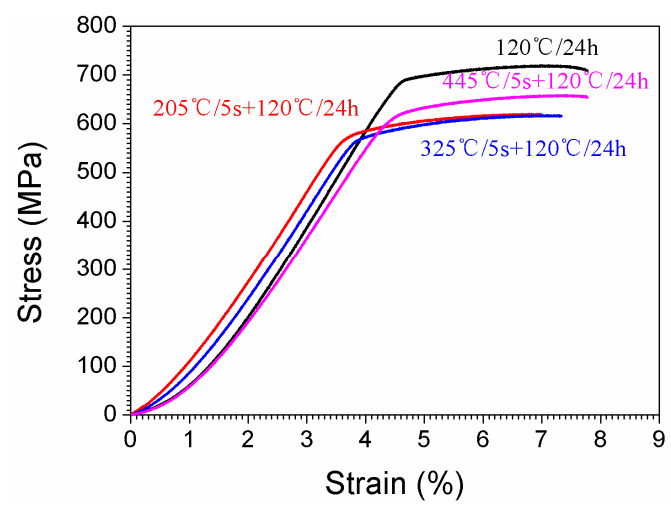

(a)

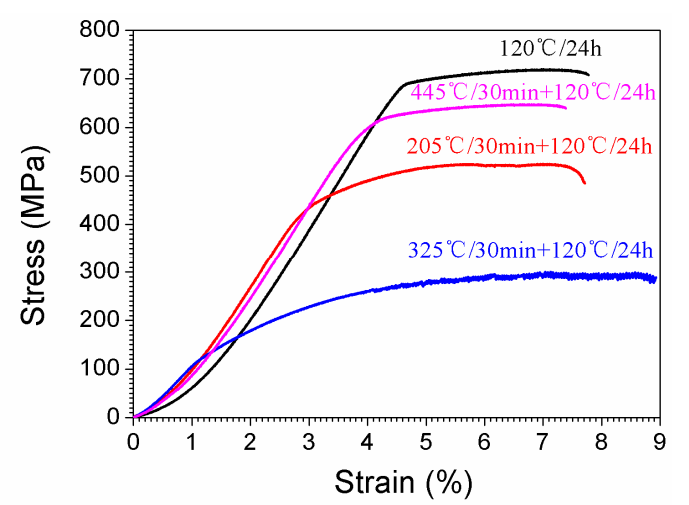

(b)

Figure 10. Stress-strain curves of the tensile samples having been isothermal heat treated at $205{ }^{\circ} \mathrm{C}$, $325{ }^{\circ} \mathrm{C}$, and $445{ }^{\circ} \mathrm{C}$ for different durations ( $5 \mathrm{~s}$ and $30 \mathrm{~min}$ ), then aging at $120{ }^{\circ} \mathrm{C}$ for $24 \mathrm{~h}$. (a) the isothermal heat treated time is $5 \mathrm{~s}$; (b) the isothermal heat treated time is $30 \mathrm{~min}$. 
Table 3. Mechanical properties of the studied specimens subjected to isothermal heat treatments for different treatment parameters.

\begin{tabular}{cccc}
\hline Sample No. & Elongation (\%) & Ultimate Tensile Strength (MPa) & Yield Strength (MPa) \\
\hline B & 7.7 & 719.8 & 699.8 \\
C/5 s & 6.9 & 620.2 & 598.2 \\
D/5 s & 7.3 & 604.4 & 578.3 \\
E $/ 5 \mathrm{~s}$ & 7.7 & 647.5 & 621.9 \\
F/30 min & 7.7 & 524.5 & 506.4 \\
G/30 min & 8.9 & 300.1 & 267.6 \\
H/30 min & 7.3 & 647.5 & 621.2 \\
\hline
\end{tabular}

\section{Discussion}

\subsection{The Quenching Sensitivity}

Temperature-time-property (TTP) curves can be established by the hardness of the samples with isothermal heat treatment and aging treatment. The nucleation rate $(k)$ can be expressed with the following equation $[37,38]$ :

$$
k=\frac{t_{c}}{k_{1}}=k_{2} \exp \left[\frac{k_{3} k_{4}^{2}}{R T\left(k_{4}-T\right)^{2}}\right] \exp \left[\frac{k_{5}}{R T}\right]
$$

where $t_{c}$ is the critical time required to precipitate a constant amount of solutes; $T$ is the IHT temperature (degree K). $R$ is the gas molar constant $\left(8.31 \mathrm{~J} \cdot \mathrm{K}^{-1}\right) . k_{1}, k_{2}, k_{3}, k_{4}$, and $k_{5}$ are materials constants that are related to the natural logarithm of the volume fraction of untransformed precipitates $\left(k_{1}\right)$, the reciprocal of the number of nucleation sites $\left(k_{2}\right)$, the formation energy of nucleation sites $\left(k_{3}\right)$, solid solution temperature $\left(k_{4}\right)$, and the diffusion activation energy $\left(k_{5}\right)$. The fitted coefficients of TTP curves from the Figure 11 by the hardness data are $2.10 \times 10^{-11}$ for $k_{2}, 1061 \mathrm{~J} / \mathrm{mol}$ for $k_{3}, 802 \mathrm{~K}$ for $k_{4}$, and $1.23 \times 10^{5} \mathrm{~J} / \mathrm{mol}$ for $k_{5}$, respectively. TTP curves are " $\mathrm{C}$ " shape, whose nose temperatures are around $325^{\circ} \mathrm{C}$ (Figure 11).

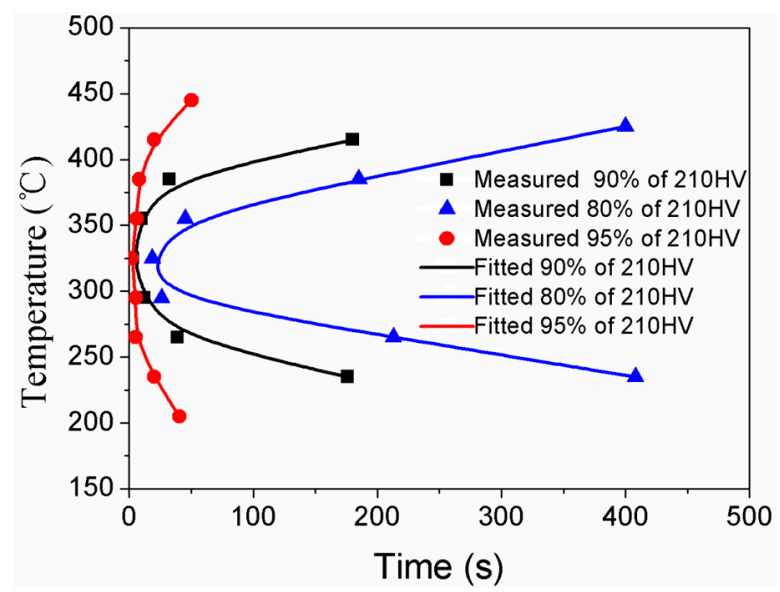

Figure 11. The time-temperature-property (TTP) curves of the studied alloy subjected to have been solid solution treated at $470{ }^{\circ} \mathrm{C}$ for $1 \mathrm{~h}$, isothermal heat treatment for various durations, and then aged at $120^{\circ} \mathrm{C}$ for $24 \mathrm{~h}$.

For the studied alloy, we divided the temperature zone during the quenching process into low-temperature zone $\left(<250{ }^{\circ} \mathrm{C}\right)$, medium-temperature zone $\left(250-400^{\circ} \mathrm{C}\right)$, and high-temperature zone $\left(>400^{\circ} \mathrm{C}\right)$. When the supersaturated solid solution were isothermal heat treated at the low-temperature zone $\left(<250{ }^{\circ} \mathrm{C}\right)$ and high-temperature zone $\left(>400^{\circ} \mathrm{C}\right)$. The hardness decreased slightly. While, if SSS 
samples were isothermal heat treated at the medium-temperature zone $\left(250-400{ }^{\circ} \mathrm{C}\right)$, the hardness decreased rapidly, indicating that the alloy presented a high quenching sensitivity and a short incubation period in the medium-temperature zone. Similar TTP curves of conventional casting 7XXX alloy have been reported by some researchers, and many methods were applied to study the quenching sensitivity. In-situ electrical resistivity measurement and differential calorimetry were employed to investigate the high temperature precipitation kinetics and TTT curves, which reveal that the nose temperature decreased from $375^{\circ} \mathrm{C}$ to $350{ }^{\circ} \mathrm{C}$ when the precipitated fraction increase [37]. Liu et al. have investigated the TTP diagram for Al-Zn-Mg-Cu alloys including 7075, 7175, 7050, 7010, 7055,7085 , and 1933. Their result demonstrated that the nose temperature of TTP diagrams changed with the chemical composition of alloys, which was $355^{\circ} \mathrm{C}$ for 7055 alloy while it was $295{ }^{\circ} \mathrm{C}$ for 7085 alloy [39]. Nie et al. reported that the aging hardness reductions for the 7085, 7050, 7150, and 7055 alloys by air quenching are up to $8.6 \%, 18.4 \%, 21 \%$, and $21.7 \%$, respectively, in comparison that that by water quenching [40]. Air quenching presents lower a quenching rate when compared with water quenching. The aging yield strength reductions for the studied alloy are $27.6 \%, 31.4 \%$, and $11.2 \%$ for sample $\mathrm{F} / 5 \mathrm{~s}$, sample $\mathrm{G} / 5 \mathrm{~s}$, and sample $\mathrm{H} / 30 \mathrm{~min}$, respectively, in comparison that with water quenching, thus a higher furnace-to-furnace transfer temperature is preferred for the studied alloy. Due to recrystallization, $\mathrm{Zr}$-containing dispersoids become incoherent with the matrix and act as effective nucleation sites for heterogeneous precipitation during slow quenching, thus $\mathrm{Zr}$ addition in the alloy inhibits recrystallization that is sensitive to the quench sensitivity [41]. The hardness of 7085 alloy increased with an increase of $\mathrm{Mg}$, which was reported by Deng et al. who have studied the quench sensitivity of $\mathrm{Al}$ alloys via depth of age hardening layer according to hardness retention value [27]. The TTP curve of 7010 alloy indicated that transformation occurred most rapidly between 250 and $400{ }^{\circ} \mathrm{C}$ [42]. For the above 7XXX alloy, the nose temperature of TTP curves were between $250-400{ }^{\circ} \mathrm{C}$, which are consistent with the result in this work $\left(325^{\circ} \mathrm{C}\right)$.

As the SSS was isothermal heat treated, some precipitates have been detected in above images and previous investigations $[37,43,44]$. High quenching sensitivity is the result of fast precipitation from the supersaturated solid solution [24]:

$$
\frac{d V \mathrm{t}}{d \mathrm{t}}=\frac{4}{3} \pi \cdot V_{0} \cdot \dot{N} \cdot \dot{G}^{3} \cdot t^{3} \cdot \exp \left(-\frac{\pi}{3} \dot{G}^{3} \dot{N} t^{4}\right)
$$

where $V_{\mathrm{t}}$ is the precipitates volume, $V_{0}$ is the sample volume, $\dot{N}$ is the nucleating rate of precipitates, $\dot{G}^{3}$ is the precipitate growing rate, and $t$ is IHT time. When the SSS samples were isothermal heat treated in the medium temperature zone $\left(250-400{ }^{\circ} \mathrm{C}\right), \dot{N} \cdot \dot{G}^{3}$ reached the maximum value. The incubation period of the studied alloy is short in medium temperature zone but long in the low-temperature zone and high-temperature zone. Thus, for the studied alloy, after solid solution treatment, the samples should be rapidly transferred into the aging treatment furnace, and the temperature of the sample during transfer process should be higher than $400{ }^{\circ} \mathrm{C}$. Meanwhile, if the sample could not be moved to the aging furnace very quickly, a water quenching should be performed for cooling down the sample temperature to lower than $250{ }^{\circ} \mathrm{C}$. Otherwise, the SSS sample would be decomposed and coarse precipitates would form on grain boundary and grain inside, resulting in undesired mechanical properties.

\subsection{Precipitation Behavior during Isothermal Heat Treatment}

The studied alloy was a precipitation hardening aluminum alloy. After the appropriate solution annealing and quenching, a supersaturated solid solution would be formed; then decomposition behavior would start from quenching, as well as aging at a low temperature. Previous investigations proved that the SSS would begin to decompose at $120{ }^{\circ} \mathrm{C}$ [45]. Generally, for the $\mathrm{Al}-\mathrm{Zn}-\mathrm{Mg}-\mathrm{Cu}-\mathrm{Zr}$ alloy, it will take $12 \mathrm{~h}$ to finish the peak aging process [43]. The precipitates size was only $5-8 \mathrm{~nm}$ in length and $1.5-3 \mathrm{~nm}$ in width. With increasing the aging temperature, the decomposition behavior 
accelerated [46]. During the isothermal heat treatment processing, few $\eta^{\prime}$ precipitates were detected when the IHT time is only $5 \mathrm{~s}$ (Figure 3b). Increasing the time to IHT $30 \mathrm{~min}$, some precipitates with a size of $80 \mathrm{~nm}$ in length and $10 \mathrm{~nm}$ in diameter were detected (Figure 3d). However, when the SSS was quenched to isothermal temperature of $325^{\circ} \mathrm{C}$ (Figure 4), even the IHT time is $5 \mathrm{~s}$, some $\eta^{\prime}$ precipitates were detected with a size of $150 \mathrm{~nm}$ in length and $20 \mathrm{~nm}$ in diameter (Figure 4a). Similarly, the SSS sample was quenched to an isothermal temperature of $445^{\circ} \mathrm{C}$, precipitation happened (Figure 5). These isothermal heat treated specimens were aging treated at $120^{\circ} \mathrm{C}$ for $24 \mathrm{~h}$, many $\eta^{\prime}-\mathrm{MgZn}_{2}$ were precipitated from the matrix. As a result of this work, an appropriate isothermal temperature required to be tailored, low-temperature zone $\left(<250^{\circ} \mathrm{C}\right)$ and high-temperature zone $\left(>400{ }^{\circ} \mathrm{C}\right)$ were worked out for the studied alloy to maintain small precipitates and high strength.

\subsection{Influence of Precipitates Size on the Strengthening Response}

Low-temperature aging treatment at $120^{\circ} \mathrm{C}$ contributed to the precipitation hardening in the studied alloy. However, the precipitation occurred in samples during transferring from the solution treated furnace to the aging furnace, and the precipitates may coarsen. The Orowan mechanism for dislocation and particles can evaluate the significant increase of yield strength by the precipitates. The increment of $\Delta \sigma_{\text {Orowan }}$ can be expressed as follows [36].

$$
\begin{gathered}
\Delta \sigma=\frac{0.81 M G b}{2 \pi(1-v)^{1 / 2}} \frac{\ln \left(d_{\mathrm{p}} / b\right)}{\left(\lambda-d_{\mathrm{p}}\right)} \\
\lambda=\frac{1}{2} d_{\mathrm{p}} \sqrt{\frac{3 \pi}{2 f_{\mathrm{v}}}}
\end{gathered}
$$

where, $M$ is the Taylor-factor ( $M$ for $\mathrm{Al}$ is 3.06); $G$ is the shear modulus (shear modulus for $\mathrm{Al}$ is $26.9 \mathrm{GPa}) ; d_{\mathrm{p}}$ is the average diameter of precipitates particle; $b$ is the Burgers vector ( $b$ for $\mathrm{Al}$ is $0.286 \mathrm{~nm}) ; v$ is the Poisson's ratio ( $v$ for $\mathrm{Al}$ is 0.33 ) [47]; $\lambda$ is the average particle plane square lattice spacing; $f_{\mathrm{v}}$ is the volume fraction of particles. To simplify the calculation, we assumed that all of the $\mathrm{Mg}$ and $\mathrm{Zn}$ atoms precipitated in the form of $\eta^{\prime}-\mathrm{MgZn} \mathrm{n}_{2}$ precipitates [48]. The volume fraction of $\mathrm{MgZn}_{2}$ precipitates can be calculated and $f_{\mathrm{v}}$ is $5.9 \%$. Therefore, the increment of $\Delta \sigma_{\text {Orowan }}$ was a function of $d_{\mathrm{p}}$ and can be calculated as follows:

$$
\Delta \sigma_{\text {Orowan }}=\frac{1286+1029 \ln d \mathrm{p}}{d \mathrm{p}}
$$

When the sample was solution-treated and immediately aged at $120^{\circ} \mathrm{C}$ for $24 \mathrm{~h}, d_{\mathrm{p}}$ was about $10 \mathrm{~nm}$ (Figure 2, sample B), the $\Delta \sigma_{\text {Orowan }}$ was $365.5 \mathrm{MPa}$. However, when the $d_{\mathrm{p}}$ was about $300 \mathrm{~nm}$ in Figure $7 \mathrm{c}$ (the alloy was isothermal treated at $325{ }^{\circ} \mathrm{C}$ for $30 \mathrm{~min}$ then aged at $120{ }^{\circ} \mathrm{C}$ for $24 \mathrm{~h}$, sample G), the $\Delta \sigma_{\text {Orowan }}$ is only $23.9 \mathrm{MPa}$. The precipitate size is a significant factor on the $\Delta \sigma_{\text {Orowan }}$ strengthening effect.

\section{Conclusions}

In summary, a high strength $\mathrm{Al}-\mathrm{Zn}-\mathrm{Mg}-\mathrm{Cu}-\mathrm{Zr}$ alloy was synthesized by using a spray deposition technology followed by hot extrusion, solution treatment, isothermal heat treatment, and aging treatment.

(1) The hardness and the ultimate tensile strength decreased with the isothermal heat treatment time. TTP curves of the studied alloy have been established, and the mechanism for high quenching sensitivity at the nose temperature zone has been discussed. TTP curves of the studied alloy are " $\mathrm{C}$ "-like ones, and the nose-tip temperatures of these curves are around $325^{\circ} \mathrm{C}$.

(2) The studied alloy presented a high quenching sensitivity at the medium-temperature zone $\left(250-400{ }^{\circ} \mathrm{C}\right)$ because in this medium temperature zone the nucleation rate of the precipitates was 
high and a significant number of precipitates formed. After solid solution treatment, precipitation appeared scarcely as specimens had been isothermal heat treated at the low-temperature zone $\left(<250{ }^{\circ} \mathrm{C}\right)$, and the high-temperature zone $\left(>400{ }^{\circ} \mathrm{C}\right)$, both of above two temperature zones were available for the industry production.

(3) The strengthening phase would precipitate as the sample aged at $120^{\circ} \mathrm{C}$, resulting in high mechanical properties. Precipitates with size of $10 \mathrm{~nm}$ would contribute a significant increase in yield strength, while ones larger than $300 \mathrm{~nm}$ contribute only little.

Acknowledgments: The authors thank to the financial support by the National Key Technology K \& D Program (2014BAC03B08), the National Key Research and Development Program of China (2016YFB0301300), the start-up funding from the Central South University, the Fundamental Research Funds for the Central Universities of Central South University (2014ZZTS018) and Hunan Provincial Innovation Foundation for Postgraduate (CX2014B048).

Author Contributions: Xiaofei Sheng and Qian Lei conceived and designed the experiments; Xiaofei Sheng performed the experiments; Xiaofei Sheng and Qian Lei analyzed the data; Mingpu Wang and Zhu Xiao contributed materials and discussions; Xiaofei Sheng and Qian Lei wrote the paper.

Conflicts of Interest: The authors declare no conflict of interest.

\section{References}

1. Huo, W.T.; Shi, J.T.; Hou, L.G.; Zhang, J.S. An improved thermo-mechanical treatment of high-strength $\mathrm{Al}-\mathrm{Zn}-\mathrm{Mg}-\mathrm{Cu}$ alloy for effective grain refinement and ductility modification. J. Mater. Process. Technol. 2017, 239, 303-314. [CrossRef]

2. Subroto, T.; Miroux, A.; Eskin, D.G.; Katgerman, L. Tensile mechanical properties, constitutive parameters and fracture characteristics of an as-cast AA7050 alloy in the near-solidus temperature regime. Mater. Sci. Eng. A 2017, 679, 28-35. [CrossRef]

3. Shi, C.J.; Lai, J.; Chen, X.G. Microstructural evolution and dynamic softening mechanisms of Al-Zn-Mg-Cu alloy during hot compressive deformation. Materials 2014, 7, 244-264. [CrossRef] [PubMed]

4. Liu, L.; Liu, F.; Zhu, M.L. Study on Mg/Al weld seam based on Zn-Mg-Al ternary alloy. Materials 2014, 7 , 1173-1187. [CrossRef] [PubMed]

5. Jiang, F.L.; Zurob, H.S.; Purdy, G.R.; Zhang, H. Characterizing precipitate evolution of an Al-Zn-Mg-Cu-based commercial alloy during artificial aging and non-isothermal heat treatments by in situ electrical resistivity monitoring. Mater. Charact. 2016, 117, 47-56. [CrossRef]

6. Viscusi, A.; Leitão, C.; Rodrigues, D.M.; Scherillo, F.; Squillace, A.; Carrino, L. Laser beam welded joints of dissimilar heat treatable aluminum alloys. J. Mater. Process. Technol. 2016, 236, 48-55. [CrossRef]

7. Xia, S.H.; Vychigzhanina, L.V.; Wang, J.T.; Alexandrov, I.V.; Sharafutdinov, A.V. Controllable bimodal structures in hypo-eutectoid $\mathrm{Cu}-\mathrm{Al}$ alloy for both high strength and tensile ductility. Mater. Sci. Eng. A 2008, 490, 471-476. [CrossRef]

8. Zhang, L.; Li, X.Y.; Nie, Z.; Huang, H.; Sun, J.T. Microstructure and mechanical properties of a new Al-Zn-Mg-Cu alloy joints welded by laser beam. Mater. Des. 2015, 83, 451-458. [CrossRef]

9. Fang, H.C.; Luo, F.H.; Chen, K.H. Effect of intermetallic phases and recrystallization on the corrosion and fracture behavior of an Al-Zn-Mg-Cu-Zr-Yb-Cr alloy. Mater. Sci. Eng. A 2017, 684, 480-490. [CrossRef]

10. Dong, J.; Cui, J.Z.; Yu, F.X.; Zhao, Z.H.; Zhuo, Y.B. A new way to cast high-alloyed Al-Zn-Mg-Cu-Zr for super-high strength and toughness. J. Mater. Process. Technol. 2006, 171, 399-404. [CrossRef]

11. Roy, S.; Nataraj, B.R.; Suwas, S.; Kumar, S.; Chattopadhyay, K. Accumulative roll bonding of aluminum alloys 2219/5086 laminates: Microstructural evolution and tensile properties. Mater. Des. 2012, 36, 529-539. [CrossRef]

12. Chen, Y.; Gao, N.; Sha, G.; Ringer, S.P.; Starink, M.J. Strengthening of an Al-Cu-Mg alloy processed by high-pressure torsion due to clusters, defects and defect-cluster complexes. Mater. Sci. Eng. A 2015, 627, 10-20. [CrossRef]

13. Shaeri, M.H.; Salehi, M.T.; Seyyedein, S.H.; Abutalebi, M.R.; Park, J.K. Microstructure and mechanical properties of Al-7075 alloy processed by equal channel angular pressing combined with aging treatment. Mater. Des. 2014, 57, 250-257. [CrossRef] 
14. Sun, N.; Apelian, D. Friction stir processing of aluminum cast alloys for high performance applications. J. Miner. Met. Mater. Soc. 2011, 63, 44-50. [CrossRef]

15. Naeem, H.T.; Mohammed, K.S.; Ahmad, K.R. Effect of friction stir processing on the microstructure and hardness of an aluminum-zinc-magnesium-copper alloy with nickel additives. Phys. Met. Metallogr. 2015, 116, 1035-1046. [CrossRef]

16. Li, Y.; Koizumi, Y.; Chiba, A. Dynamic recrystallization behavior of biomedical Co-29Cr-6Mo-0.16N alloy with extremely low stacking fault energy. Mater. Sci. Eng. A 2016, 668, 48-54. [CrossRef]

17. Li, Y.; Li, J.; Koizumi, Y.; Chiba, A. Dynamic recrystallization behavior of biomedical Co-29Cr-6Mo-0.16N alloy. Mater. Charact. 2016, 118, 50-56. [CrossRef]

18. Feng, W.; Xiong, B.Q.; Zhang, Y.G.; Liu, H.W.; He, X.Q.; He, H.W.; He, X.Q. Microstructural development of spray-deposited Al-Zn-Mg-Cu alloy during subsequent processing. J. Alloys Compd. 2009, 477, 616-621. [CrossRef]

19. Jia, Y.D.; Cao, F.Y.; Guo, S.; Ma, P.; Liu, J.S.; Sun, J.F. Hot deformation behavior of spray-deposited Al-Zn-Mg-Cu alloy. Mater. Des. 2014, 53, 79-85. [CrossRef]

20. Azimi, A.; Shokuhfar, A.; Zolriasatein, A. Nanostructured Al-Zn-Mg-Cu-Zr alloy prepared by mechanical alloying followed by hot pressing. Mater. Sci. Eng. A 2014, 595, 124-130. [CrossRef]

21. Yan, L.M.; Shen, J.; Li, Z.B.; Li, J.P.; Yan, X.D. Microstructure evolution of Al-Zn-Mg-Cu-Zr alloy during hot deformation. Rare Met. 2010, 29, 426-432. [CrossRef]

22. Li, F.X.; Liu, Y.Z.; Yi, J.H. Microstructural evolution of gas atomized Al-Zn-Mg-Cu-Zr powders during semi-solid rolling process. Trans. Nonferrous Met. Soc. China 2014, 24, 2475-2481. [CrossRef]

23. Mathur, P.; Apelian, D.; Lawley, A. Analysis of the spray deposition process. Acta Metall. 1989, 37, 429-443. [CrossRef]

24. Li, H.C.; Cao, F.Y.; Guo, S.; Ning, Z.L.; Liu, Z.Y.; Jia, Y.D.; Scudino, S.; Gemming, T.; Sun, J.F. Microstructures and properties evolution of spray-deposited $\mathrm{Al}-\mathrm{Zn}-\mathrm{Mg}-\mathrm{Cu}-\mathrm{Zr}$ alloys with scandium addition. J. Alloys Compd. 2017, 691, 482-488. [CrossRef]

25. Liu, B.; Lei, Q.; Xie, L.Q.; Wang, M.P.; Li, Z. Microstructure and mechanical properties of high product of strength and elongation Al-Zn-Mg-Cu-Zr alloys fabricated by spray deposition. Mater. Des. 2016, 96, 217-223. [CrossRef]

26. Yu, H.C.; Wang, M.P.; Sheng, X.F.; Li, Z.; Chen, L.B.; Lei, Q.; Chen, C.; Jia, Y.L.; Xiao, Z.; Chen, W.; et al. Microstructure and tensile properties of large-size 7055 aluminum billets fabricated by spray forming rapid solidification technology. J. Alloys Compd. 2013, 578, 208-214. [CrossRef]

27. Dorward, R.C.; Beerntsen, D.J. Grain structure and quench-rate effects on strength and toughness of AA7050 Al-Zn-Mg-Cu-Zr alloy plate. Metall. Mater. Trans. A 1995, 26, 2481-2484. [CrossRef]

28. Sharma, M.M.; Amateau, M.F.; Eden, T.J. Mesoscopic structure control of spray formed high strength Al-Zn-Mg-Cu alloys. Acta Mater. 2005, 53, 2919-2924. [CrossRef]

29. Liu, S.D.; Zhang, X.M.; Chen, M.A.; You, J.H.; Zhang, X.Y. Effect of Zr content on quench sensitivity of AIZnMgCu alloys. Trans. Nonferrous Met. Soc. China 2007, 17, 787-792. [CrossRef]

30. Cai, Y.H.; Liang, R.G.; Su, Z.P.; Zhang, J.S. Microstructure of spray formed Al-Zn-Mg-Cu alloy with Mn addition. Trans. Nonferrous Met. Soc. China 2011, 21, 9-14. [CrossRef]

31. Shen, L.N.; Li, Z.; Dong, Q.Y.; Xiao, Z.; Li, S.; Lei, Q. Microstructure evolution and quench sensitivity of Cu-10Ni-3Al-0.8 Si alloy during isothermal treatment. J. Mater. Res. 2015, 30, 736-744. [CrossRef]

32. Sheng, X.F.; Lei, Q.; Xiao, Z.; Wang, M. Hot deformation behavior of a spray deposited Al-8.31Zn-2.07Mg-2.46Cu-0.12Zr alloy. Metals 2017, 7, 299. [CrossRef]

33. Lia, X.Z.; Hansena, V.; Gjonnesa, J.; Wallenbergb, L.R. HREM study and structure modeling of the $\eta^{\prime}$ phase, the hardening precipitates in commercial Al-Zn-Mg alloys. Acta Mater. 1999, 47, 2651-2659. [CrossRef]

34. Liu, J.Z.; Chen, J.H.; Yang, X.B.; Ren, S.; Wu, C.L.; Xu, H.Y.; Zou, J. Revisiting the precipitation sequence in Al-Zn-Mg-based alloys by high-resolution transmission electron microscopy. Scr. Mater. 2010, 63, 1061-1064. [CrossRef]

35. Totten, G.E.; MacKenzie, D.S. Handbook of Aluminum; Marcel Dekker Inc.: New York, BY, USA, 2003; Volume 1, pp. 287-288, ISBN 0824704940.

36. Lityńska-Dobrzyńska, L.; Dutkiewicz, J.; Maziarz, W.; Góral, A. Microstructure of rapidly solidified Al-12Zn-3Mg-1.5Cu alloy with Zr and Sc additions. Mater. Trans. 2011, 52, 309-314. [CrossRef] 
37. Robinson, J.S.; Cudd, R.L.; Tanner, D.A.; Dolan, G.P. Quench sensitivity and tensile property inhomogeneity in 7010 forgings. J. Mater. Process. Technol. 2001, 119, 261-267. [CrossRef]

38. Evancho, J.W.; Staley, J.T. Kinetics of precipitation in aluminum alloys during continuous cooling. Metall. Trans. 1974, 5, 43-47.

39. Archambaulta, P.; Godard, D. High temperature precipitation kinetics and ttt curve of a 7xxx alloy by in-situ electrical resistivity measurements and differential calorimetry. Scr. Mater. 2000, 42, 675-680. [CrossRef]

40. Nie, B.; Liu, P.; Zhou, T.; Xie, Y.J. Evaluation of the quenching sensitivity of Al-Zn-Mg-Cu-Zr aluminum alloys by mole fraction of equilibrium phases. In Proceedings of the 13th International Conference on Aluminum Alloys (ICAA13), Pittsburgh, PA, USA, 3-7 June 2012; Weiland, H., Rollett, A.D., Cassada, W.A., Eds.; Springer: Cham, Switzerland, 2012; pp. 331-336. [CrossRef]

41. Liu, S.D.; Zhong, Q.M.; Zhang, Y.; Liu, W.J.; Zhang, X.M.; Deng, Y.L. Investigation of quench sensitivity of high strength Al-Zn-Mg-Cu alloys by time-temperature-properties diagrams. Mater. Des. 2010, 31, 3116-3120. [CrossRef]

42. Deng, Y.L.; Wan, L.; Zhang, Y.Y.; Zhang, X.M. Influence of Mg content on quench sensitivity of Al-Zn-Mg-Cu aluminum alloys. J. Alloys Compd. 2011, 509, 4636-4642. [CrossRef]

43. Du, Z.W.; Sun, Z.M.; Shao, B.L.; Zhou, T.T.; Chen, C.Q. Quantitative evaluation of precipitates in an Al-Zn-Mg-Cu alloy after isothermal aging. Mater. Charact. 2006, 56, 121-128. [CrossRef]

44. Yang, X.B.; Chen, J.H.; Liu, J.Z.; Liu, P.; Qin, F.; Cheng, Y.L.; Wu, C.L. Spherical constituent particles formed by a multistage solution treatment in Al-Zn-Mg-Cu alloys. Mater. Charact. 2013, 83, 79-88. [CrossRef]

45. Yang, W.C.; Ji, S.X.; Zhang, Q.; Wang, M.P. Investigation of mechanical and corrosion properties of an $\mathrm{Al}-\mathrm{Zn}-\mathrm{Mg}-\mathrm{Cu}$ alloy under various ageing conditions and interface analysis of $\eta^{\prime}$ precipitate. Mater. Des. 2015, 85, 752-761. [CrossRef]

46. Yang, W.C.; Ji, S.X.; Wang, M.P.; Li, Z. Precipitation behavior of Al-Zn-Mg-Cu alloy and diffraction analysis from $\eta^{\prime}$ precipitates in four variants. J. Alloys Compd. 2014, 610, 623-629. [CrossRef]

47. Cao, L.F.; Wang, M.P.; Guo, M.X.; Li, Z. Heat treatment of modified 6005A alloy for vehicles. Trans. Mater. Heat Treat. 2004, 25, 619-622.

48. Yu, H.C.; Wang, M.P.; Jia, Y.L.; Xiao, Z.; Chen, C.; Lei, Q.; Li, Z.; Chen, W.; Zhang, H.; Wang, Y.G.; et al. High strength and large ductility in spray-deposited Al-Zn-Mg-Cu alloys. J. Alloys Compd. 2014, 601, 120-125. [CrossRef] 